\title{
VARIASI METODE AERASI, KOAGULASI, DAN FILTRASI DENGAN PASIR PANTAI DALAM MENINGKATKAN KUALITAS AIR SUMUR GALI DI PESISIR PANTAI
}

\author{
Hidayatul Azizah', Abdul Khair ${ }^{2}$ \\ Poltekkes Kemenkes Banjarmasin Jurusan Kesehatan Lingkungan \\ Jl. H. Mistar Cokrokusumo No. 1A, Banjarbaru, Kalimantan Selatan, 70714 \\ E-mail : Hidayatulazizah28@gmail.com
}

\begin{abstract}
Well water dug in the coastal area of Kabupaten Tanah Laut generally have qualities that do not meet the requirements. Preliminary test results show that $\mathrm{pH}$ and $\mathrm{Fe}$ has exceeded the quality standard, this study aims to determine the ability variance of Aeration, Coagulation and Filtration with beach sand media in improving quality of clean water in the coast areas in terms of turbidity, $\mathrm{pH}$, and Fe parameters. The research type is experimental, and the design is Pre-test post-test with control group design. Data analysis was using Paired Sample T-Test and Wilcoxon Test. The result of measurement of dug well water in turbidity parameter of the best method was Aeration - Coagulation - Filtration with 92,47\%, percentage whereas poor water treatment was using Coagulation - Filtration method with $32,56 \%$, at $\mathrm{pH}$ parameter all variations of water treatment method have the same ability with $40,00 \%$ percentage, on the parameter of iron content the best method was Aeration - Coagulation Filtration with $99.95 \%$ percentage, while the less was using Coagulation - Filtration method with $60.75 \%$ percentage. Thus it can be concluded that all methods of water treatment used to improve the quality of dug well water in the coast areas. Variance of water treatment methods can be applied to communities in coast areas as one of the alternatives in improving the quality of clean water.
\end{abstract}

Keywords : Water Treatment; Aeration; Coagulation; Filtration

Copyright (C) 2021 Jurnal Skala Kesehatan. Politeknik Kesehatan Banjarmasin All rights reserved

Corresponding Author:

Hidayatul Azizah,

Poltekkes Kemenkes Banjarmasin Jurusan Kesling

Email : hidayatulazizah28@gmail.com 
Abstrak : Air sumur gali di daerah pesisir Kabupaten Tanah Laut umumnya memiliki kualitas yang tidak memenuhi persyaratan, hasil uji pendahuluan menunjukkan bahwa pH dan Fe telah melampaui baku mutu, oleh karena itu penelitian ini bertujuan untuk mengetahui kemampuan variasi metode Aerasi, Koagulasi dan Filtrasi dengan media pasir pantai dalam meningkatkan kualitas air bersih di wilayah pesisir pantai ditinjau dari parameter kekeruhan, $\mathrm{pH}$ dan Fe. Jenis penelitian bersifat eksperimental, desain penelitian menggunakan Pre-test post-test with control group design. Analisis data menggunakan uji statistik Paired Sample T-Test dan Uji Wilcoxon. Hasil pengukuran air sumur gali parameter kekeruhan untuk metode yang paling baik adalah metode Aerasi - Koagulasi - Filtrasi dengan persentase 92.47\%, sedangkan metode pengolahan air yang kurang baik adalah metode Koagulasi - Filtrasi dengan persentase $32.56 \%$, pada parameter $\mathrm{pH}$ seluruh variasi metode pengolahan air memiliki kemampuan yang sama yaitu dengan persentase $40.00 \%$, pada parameter kadar besi metode yang paling baik adalah metode Aerasi - Koagulasi - Filtrasi dengan persentase $99.95 \%$, sedangkan metode yang kurang baik adalah metode Koagulasi - Filtrasi dengan persentase 60.75\%. Dengan demikian dapat disimpulkan bahwa semua metode pengolahan air yang digunakan mampu meningkatkan kualitas air sumur gali di wilayah pesisir pantai, variasi metode tersebut dapat diaplikasikan pada masyarakat sebagai salah satu alternatif pengolahan air bersih.

Kata kunci : Pengolahan Air; Aerasi; Koagulasi; Filtrasi

\section{PENDAHULUAN}

Menurut World Assesment Programme (WWAP), bentukan United Nation Educational, Scientific and Cultural Organization (UNESCO), Menegaskan bahwa krisis air di dunia memberi dampak yang buruk dan dapat membangkitkan epidemi penyakit yang merenggut nyawa. Indonesia merupakan salah satu negara yang memiliki berbagai macam permasalahan air bersih baik masalah fisik, kimia, maupun mikrobiologi, hampir $80 \%$ masyarakat Indonesia mengkonsumsi air yang tidak sehat sehingga dapat menyebabkan berbagai macam penyakit (1).

Kabupaten Tanah Laut merupakan salah satu Kabupaten di Kalimantan Selatan, yang memiliki garis pantai yang cukup panjang $\pm 200 \mathrm{Km}$ (2). Luasnya pesisir pantai yang ada menyebabkan sebagian masyarakat mengalami berbagai macam permasalahan terhadap air bersih, hal ini di sebabkan oleh kondisi geografis dan kebiasaan masyarakat pesisir yang membuat sumur gali dangkal yang tidak memenuhi persyaratan seperti konstruksi sumur yang tidak memiliki lantai, dinding dan letak sumur yang dekat dengan sumber pencemar sehingga kualitas air sumur gali daerah tersebut sangat rendah, dilihat dari kualitas fisik air dapat di lihat bahwa air tersebut keruh, berbau, dan berasa serta terlihat mengkilap, air yang di gunakan tersebut menyebabkan penampungan air berkarat, baju yang berubah warna menjadi kekuningan, dan pipa untuk mengalirkan air cepat tersumbat, berbagai permasalahan tersebut menyebabkan air yang tersedia tidak dapat dikonsumsi sehingga masyarakat terpaksa membeli air bersih untuk kebutuhan makan dan minum, sebagian besar masyarakat yang tidak mampu membeli air terpaksa menggunakan air sumur yang ada untuk di konsumsi.

Berdasarkan studi pendahuluan yang telah di lakukan pada sampel air sumur gali di Wilayah pesisir pantai Desa Kuala Tambangan didapatkan hasil pemeriksaan pH yaitu 5 dan kadar besi (Fe) sebesar 2,68 mg/l dan 2,39 mg/l sedangkan $\mathrm{pH}$ yang dianjurkan dan kadar maksimum kadar besi (Fe) dalam Peraturan Menteri Kesehatan Republik Indonesia Nomor 32 Tahun 2017 tentang Standar Baku Mutu Kesehatan Lingkungan dan Persyaratan Kesehatan Air untuk Keperluan Higiene Sanitasi, Kolam Renang, Solus Per Aqua dan Pemandian Umum adalah 6,5 - 8,5 untuk pH dalam air bersih dan maksimum $1 \mathrm{mg} / \mathrm{l}$ untuk $\mathrm{Fe}$ (3), dengan demikian dapat disimpulkan bahwa air sumur gali tersebut mengandung $\mathrm{pH}$ yang asam dan kadar besi yang tinggi dan melebihi baku mutu. Untuk mengatasi permasalahan tersebut di butuhkan teknologi pengolahan air yang sesuai dan tepat guna untuk meningkatkan kualitas dan kuantitas air bersih di wilayah pesisir pantai Kabupaten Tanah Laut. 


\section{BAHAN DAN m}

Jenis penelitian yang digunakan bersifat eksperimental yaitu untuk mengetahui suatu gejala/pengaruh yang timbul, sebagai akibat dari adanya perlakuan tertentu (4). Jenis penelitian ini untuk mengetahui efektifitas variasi metode filtrasi, aerasi - filtrasi, koagulasi filtrasi dan gabungan metode aerasi - koagulasi - filtrasi dengan media pasir pantai dalam meningkatkan kualitas air sumur gali di wilayah pesisir pantai ditinjau dari parameter kekeruhan, $\mathrm{pH}$ dan Fe. Desain penelitian menggunakan Pre-test post-test with control group design, adapun prosedur pengolahan air dalam penelitian ini yaitu dengan cara memasukkan air sumur gali kedalam wadah penampungan air kemudian dilakukan proses Aerasi menggunakan Aerator pompa submersible dilanjutkan dengan proses Koagulasi yaitu penambahan koagulan berupa kapur dan tawas kemudian air dialirkan melalui media filter pasir pantai dengan demikian air yang telah diolah telah memenuhi persyaratan kualitas air bersih ditinjau dari parameter kekeruhan, $\mathrm{pH}$ dan kadar besi, kemudian data hasil pengolahan air tersebut dianalisis menggunakan uji statistik Paired Sample T-Test dan Uji Wilcoxon.

\section{HASIL DAN PEMBAHASAN}

a. Hasil Pemeriksaan Kekeruhan

Hasil pemeriksaan kekeruhan dapat dilihat pada tabel berikut :

Tabel 1. Hasil Pemeriksaan Air Sumur Gali Parameter Kekeruhan

\begin{tabular}{lcc}
\hline \multicolumn{1}{c}{$\begin{array}{c}\text { Variasi Metode } \\
\text { Pengolahan Air }\end{array}$} & $\begin{array}{c}\text { KEKERUHAN (NTU) } \\
\text { Sebelum Pengolahan } \\
\left(\mathrm{P}_{1}\right)\end{array}$ & $\begin{array}{c}\text { Sesudah Pengolahan } \\
\left(\mathrm{P}_{2}\right)\end{array}$ \\
\hline Kontrol $(\mathrm{X})$ & & 21,2 \\
Filtrasi $\left(\mathrm{X}_{1}\right)$ & 20,3 & 7,2 \\
Aerasi - filtrasi $\left(\mathrm{X}_{2}\right)$ & 21,8 & 13,6 \\
Koagulasi - filtrasi $\left(\mathrm{X}_{3}\right)$ & 22,3 & 15,1 \\
Aerasi - koagulasi - filtrasi $\left(\mathrm{X}_{4}\right)$ & 22,2 & 1,7 \\
\hline
\end{tabular}

Pada parameter kekeruhan dapat diketahui berdasarkan Peraturan Menteri Kesehatan Republik Indonesia No. 32 Tahun 2017 tentang Standar Baku Mutu Kesehatan Lingkungan dan Persyaratan Kesehatan Air untuk Keperluan Higiene Sanitasi, Kolam Renang, Solus Per Aqua dan Pemandian Umum menerangkan bahwa hasil pemeriksaan kekeruhan pada air sumur gali di Desa Kuala Tambangan masih memenuhi baku mutu kesehatan lingkungan (25 NTU).

Berdasarkan penelitian yang telah dilakukan dapat diketahui bahwa semua metode pengolahan air yang digunakan mampu menurunkan kekeruhan pada air sumur gali di wilayah pesisir pantai dan metode pengolahan air yang paling baik dalam penelitian ini adalah dengan menggunakan metode Aerasi - Koagulasi - Filtrasi dengan nilai rata - rata kekeruhan sebelum dilakukan pengolahan sebesar 22.2 NTU dan nilai rata - rata sesudah pengolahan sebesar 1.7 NTU dengan persentase penurunan kekeruhan sebesar $92.47 \%$, Hal ini dikarenakan pada proses Aerasi kadar besi di dalam air mengalami perubahan bentuk dari ferro $\left(\mathrm{Fe}^{2+}\right)$ menjadi ferri $\left(\mathrm{Fe}^{3+}\right)$ apabila proses aerasi sempurna maka partikel yang terbentuk akan semakin besar kemudian pada proses Koagulasi pembentukan gumpalan partikel - partikel yang ada di dalam air semakin cepat sehingga pada proses Filtrasi partikel - partikel tersebut dapat tersaring dengan baik, sedangkan metode pengolahan air yang kurang baik dalam penelitian ini adalah dengan menggunakan metode Koagulasi - Filtrasi dengan nilai rata - rata kekeruhan sebelum pengolahan 
sebesar 22.3 NTU dan nilai rata - rata sesudah pengolahan sebesar 15.1 NTU dengan persentase penurunan kekeruhan sebesar $32.56 \%$. Hal ini dikarenakan pada proses Koagulasi pembentukan gumpalan partikel - partikel yang ada di dalam air semakin cepat namun karena tidak adanya proses sedimentasi menyebabkan gumpalan tersebut tidak terbentuk sempurna dan pada proses Filtrasi air dialirkan menggunakan pompa bertekanan sehingga menyebabkan gumpalan tersebut kembali pecah dan tidak dapat tersaring dengan baik sehingga menyebabkan persentase penurunan kekeruhan rendah.

b. Hasil Pemeriksaan pH

Hasil pemeriksaan kekeruhan dapat dilihat pada tabel berikut :

Tabel 2. Hasil Pemeriksaan Air Sumur Gali Parameter pH

\begin{tabular}{lccc}
\hline $\begin{array}{c}\text { Variasi sampel } \\
\text { Pengolahan Air }\end{array}$ & $\begin{array}{c}\text { Sebelum Pengolahan } \\
\left(\mathrm{P}_{1}\right)\end{array}$ & $\begin{array}{c}\mathrm{pH} \\
\text { Sesudah Pengolahan } \\
\left(\mathrm{P}_{2}\right)\end{array}$ \\
\hline Kontrol $(\mathrm{X})$ & & 5 & 7 \\
Filtrasi $\left(\mathrm{X}_{1}\right)$ & 5 & & 7 \\
Aerasi - filtrasi $\left(\mathrm{X}_{2}\right)$ & 5 & 7 \\
Koagulasi - filtrasi $\left(\mathrm{X}_{3}\right)$ & 5 & & 7 \\
Aerasi - koagulasi - filtrasi $\left(\mathrm{X}_{4}\right)$ & 5 & & \\
\hline
\end{tabular}

Pada parameter $\mathrm{pH}$ dapat diketahui berdasarkan Peraturan Menteri Kesehatan Republik Indonesia No. 32 Tahun 2017 tentang Standar Baku Mutu Kesehatan Lingkungan dan Persyaratan Kesehatan Air untuk Keperluan Higiene Sanitasi, Kolam Renang, Solus Per Aqua dan Pemandian Umum menerangkan bahwa hasil pemeriksaan $\mathrm{pH}$ pada air sumur gali di wilayah pesisir pantai Kabupaten Tanah Laut tersebut tidak memenuhi baku mutu kesehatan lingkungan $(6.5-8.5)$.

Berdasarkan penelitian yang telah dilakukan dapat diketahui bahwa semua metode pengolahan air yang digunakan mampu dalam meningkatkan $\mathrm{pH}$ air dan semua metode pengolahan air memiliki kemampuan yang sama dalam meningkatkan kualitas air sumur gali ditinjau dari parameter $\mathrm{pH}$ yaitu dengan nilai rata - rata $\mathrm{pH}$ sebelum dilakukan pengolahan sebesar 5 dan nilai rata - rata sesudah dilakukan pengolahan sebesar 7 dengan persentase peningkatan $\mathrm{pH}$ air sebesar $40.00 \%$. Hal ini dikarenakan semakin tinggi $\mathrm{pH}$ air maka kecepatan reaksi oksidasi pada proses aerasi semakin cepat. peningkatan $\mathrm{pH}$ juga dikarenakan kadar $\mathrm{CO}_{2}$ yang dihilangkan selama proses berlangsung (5), kemudian proses Koagulasi yang mana koagulan yang digunakan adalah tawas dan kapur yang digunakan untuk menetralkan $\mathrm{pH}$ air dan yang terakhir adalah proses Filtrasi menggunakan pasir pantai, seperti yang diketahui pasir pantai memiliki kandungan zat kapur yang tinggi yang terbentuk dari sisa - sisa cangkang biota laut seperti kerang dan lain - lain serta sisa - sisa dari cangkang hewan air seperti udang dan kepiting, dengan demikian kitosan ini mampu menetralkan $\mathrm{pH}$ pada air.

c. Hasil Pemeriksaan Kadar Besi

Hasil pemeriksaan kekeruhan dapat dilihat pada tabel berikut :

Tabel 3. Hasil Pemeriksaan Air Sumur Gali Parameter Kadar Besi (Fe)

\begin{tabular}{|c|c|c|}
\hline \multirow[b]{2}{*}{$\begin{array}{l}\text { Variasi sampel } \\
\text { Pengolahan Air }\end{array}$} & \multicolumn{2}{|c|}{ KADAR BESI (mg/l) } \\
\hline & $\begin{array}{c}\text { Sebelum Pengolahan } \\
\left(P_{1}\right)\end{array}$ & $\begin{array}{l}\text { Sesudah Pengolahan } \\
\qquad\left(P_{2}\right)\end{array}$ \\
\hline Kontrol (X) & \multicolumn{2}{|c|}{2,07} \\
\hline Filtrasi $\left(\mathrm{X}_{1}\right)$ & 1,61 & 0,27 \\
\hline
\end{tabular}




\begin{tabular}{lcc} 
Aerasi - filtrasi $\left(X_{2}\right)$ & 1,89 & 0,74 \\
Koagulasi - filtrasi $\left(X_{3}\right)$ & 2,30 & 0,07 \\
Aerasi - koagulasi - filtrasi $\left(X_{4}\right)$ & 2,27 & $<0,0017$ \\
\hline
\end{tabular}

Pada parameter kadar besi (Fe) dapat diketahui berdasarkan Peraturan Menteri Kesehatan Republik Indonesia No. 32 Tahun 2017 tentang Standar Baku Mutu Kesehatan Lingkungan dan Persyaratan Kesehatan Air untuk Keperluan Higiene Sanitasi, Kolam Renang, Solus Per Aqua dan Pemandian Umum menerangkan bahwa hasil pemeriksaan kadar besi $(\mathrm{Fe}$ ) pada air sumur gali di wilayah pesisir pantai Kabupaten Tanah Laut tersebut melebihi baku mutu kualitas air bersih (Maksimum $1 \mathrm{mg} / \mathrm{l}$ ).

Berdasarkan penelitian yang telah dilakukan dapat diketahui bahwa semua metode pengolahan air yang digunakan mampu dalam menurunkan kadar besi (Fe) dan metode pengolahan air yang paling baik dalam menurunkan kadar besi ( $\mathrm{Fe}$ ) adalah dengan menggunakan metode Aerasi - Koagulasi - Filtrasi dengan nilai rata - rata kadar besi (Fe) sebelum dilakukan pengolahan sebesar $2.27 \mathrm{mg} / \mathrm{l}$ dan nilai rata - rata sesudah dilakukan pengolahan sebesar $0.0017 \mathrm{mg} / \mathrm{l}$ dengan persentase penurunan kadar besi (Fe) sebesar $99.95 \%$, hal ini dikarenakan pada proses aerasi yang digunakan untuk mengubah kadar besi (Fe) dari bentuk $\mathrm{Fe}^{2+}$ terlarut menjadi $\mathrm{Fe}^{3+}$ apabila proses aerasi sempurna maka partikel yang terbentuk akan semakin besar, selain itu koagulan yang digunakan seperti tawas yang berfungsi sebagai pembentuk gumpalan (Flok) partikel yang terlarut dan kapur yang berfungsi meningkatkan $\mathrm{pH}$ sehingga dengan meningkatnya $\mathrm{pH}$ tersebut maka kadar besi dalam air tidak mudah larut dan pada proses Filtrasi menggunakan media pasir pantai yang memiliki kandungan kitosan. Kitosan adalah suatu polisakarida berbentuk linier yang terdiri dari monomer $N$-asetilglukosamin (GlcNAc) dan D-glukosamin $(G / c N)$. Bentukan derivatif deasetilasi dari polimer ini adalah kitin yang mana kitosan ini terbentuk dari sisa - sisa cangkang biota laut seperti kerang dan lain lain serta sisa - sisa dari cangkang hewan air seperti udang dan kepiting (6), dengan demikian kitosan ini mampu menetralkan menangkap dan menyaring logam - logam yang terdapat di dalam air khususnya kadar besi (Fe).

Sedangkan metode pengolahan air yang paling buruk dalam meningkatkan kualitas air sumur gali parameter kadar besi ( $\mathrm{Fe}$ ) adalah dengan menggunakan metode Aerasi Filtrasi dengan nilai rata - rata kadar besi $(\mathrm{Fe})$ sebelum dilakukan pengolahan sebesar $1.89 \mathrm{mg} / \mathrm{l}$ dan nilai rata - rata sesudah dilakukan pengolahan sebesar $0.74 \mathrm{mg} / \mathrm{l}$ dengan persentase penurunan kadar besi (Fe) sebesar $60.75 \%$, hal ini dikarenakan pada proses Aerasi kadar besi di dalam air mengalami perubahan bentuk dari ferro $\left(\mathrm{Fe}^{2+}\right)$ menjadi ferri $\left(\mathrm{Fe}^{3+}\right)$ apabila proses aerasi sempurna maka partikel yang terbentuk akan semakin besar sedangkan proses aerasi yang tidak sempurna menyebabkan partikel berukuran kecil atau yang biasa disebut dengan koloid (5), selain itu proses aerasi yang terlalu cepat (15 menit) juga menyebabkan reaksi oksidasi besi dengan oksigen (udara) semakin sedikit dan menyebabkan proses aerasi menjadi tidak sempurna menyebabkan proses filtrasi menjadi tidak efektif karena tidak mampu menyaring koloid - koloid tersebut. 


\section{KESIMPULAN DAN SARAN}

A. Kesimpulan

1. Kualitas air sumur gali di Desa Kuala Tambangan untuk kekeruhan rata - rata 21,65 NTU, pH rata - rata 5 dan kadar besi $(\mathrm{Fe})$ rata - rata 2,02 mg/l.

2. Perbedaan kualitas air sumur gali untuk kekeruhan berkisar antara 19,99 - 23,5 NTU menjadi 0,89-15,28 NTU, untuk pH rata - rata 5 menjadi 7 dan untuk kadar besi (Fe) berkisar antara 1,49-2,36 mg/l menjadi $<0,0017-1,25 \mathrm{mg} / \mathrm{l}$.

3. Efisiensi peningkatan kualitas air sumur gali parameter kekeruhan sebesar $92,47 \%$, untuk $\mathrm{pH}$ sebesar $40.00 \%$ dan untuk kadar besi (Fe) sebesar $99.95 \%$. Metode pengolahan air yang paling efektif dalam penelitian ini adalah metode Aerasi -

B. Saran Koagulasi - Filtrasi.

1. Sebaiknya waktu dalam proses aerasi di tambah hingga 1 jam dan kadar koagulan yang sebaiknya lebih dirincikan lagi.

2. Sebaiknya dilakukan proses pengendapan setelah proses Aerasi dan proses Koagulasi agar gumpalan - gumpalan (Flok) yang telah terbentuk dapat tersaring dengan mudah pada proses Filtrasi.

3. Sebaiknya posisi tempat penampungan air kotor dipindahkan kebagian atas sehingga dalam proses pengaliran air tidak perlu menggunakan pompa air bertekanan.

\section{DAFTAR PUSTAKA}

1. United Nations Educational Scientific and Cultural Organization (UNESCO). Water in a changing world. The United Nations World Water Development Report 2 (WWDR2). World Water Assessment Programme (WWAP). Ecological 2009. 1-429 p.

2. Kuswoyo A. Pemetaan Potensi Air Tanah Sebagai Sumber Air Bersih Di Daerah Pesisir Pantai Batakan Kabupaten Tanah Laut. Sumber Air. 2014;3(1):1-10.

3. Kementerian Kesehatan Republik Indonesia. Peraturan Menteri Kesehatan Republik Indonesia Nomor 32 tahun 2017 Tentang Standar Baku Mutu Kesehatan Lingkungan dan Persyaratan Kesehatan Air untuk Keperluan Higiene Sanitasi, Kolam Renang, Solus Per Aqua, dan Pemandian Umum. Peratur Menteri Kesehat Republik Indones. 2017;10-5.

4. Notoatmojo S. Metodologi Penelitian Kesehatan. Jakarta: Rieneka Cipta; 2012.

5. Lingkungan JT, Batara K, Zaman B, Oktiawan W, Teknik D, Fakultas L, et al. PENGARUH DEBIT UDARA DAN WAKTU AERASI TEHADAP. 2017;6(1).

6. Wiyarsi A, Priyambodo E. Pengaruh Konsentrasi Kitosan dari Cangkang Udang terhadap Efisiensi Penjerapan Logam Berat. 2008. 